\title{
Spatio-temporal dynamics of the nudibranch Doris kyolis living on the sponge Halichondria melanadocia
}

\author{
Enrique Ávila ${ }^{1 *}{ }^{\circ}$, Yenny Cancino-Magaña ${ }^{1} \odot$, María Amparo Rodríguez-Santiago ${ }^{\circledR}$, Manuel Ballesteros ${ }^{3}$ \\ 1 Universidad Nacional Autónoma de México, Instituto de Ciencias del Mar y Limnología (Estación El Carmen) - Carretera Carmen- \\ Puerto Real km 9.5, 24157 Ciudad del Carmen, Campeche, México. \\ ${ }^{2}$ CONACYT - Universidad Autónoma del Carmen, Facultad de Ciencias Naturales, Centro de Investigación de Ciencias Ambientales - \\ Ave. Laguna de Términos s/n, Col. Renovación 2da Sección, 24155 Ciudad del Carmen, Campeche, México. \\ ${ }^{3}$ Universitat de Barcelona, Departament de Biología Evolutiva, Ecologia i Ciències Ambientals - Diagonal, 643 - 08028 Barcelona - Spain \\ *Corresponding author: kike@ola.icmyl.unam.mx
}

Along with other invertebrates, hawksbill turtles, and fishes, nudibranchs are among the main sponge predators. These organisms are able to feed on sponges that typically contain a high level of secondary metabolites, which they incorporate into their body and can be stored in glands (mantle dermal formations [MDFs]) to be used for their own defense (Rogers and Paul, 1991; Wägele et al., 2006). These feeding and defensive benefits entail that many nudibranch species specialize in just one prey species or taxonomic group, suggesting an important role in the food web of benthic ecosystems (Becerro et al., 1998; Rudman and Bergquist, 2007). However, despite the important progress in understanding these interspecific relationships, there is almost no information about these species' population dynamics in the localities they inhabit (Rogers and Paul, 1991; Knowlton and Highsmith, 2000; Page et al., 2011). This is important, especially because these predators (at high densities) may play a role in regulating the populations of their sponge prey and influence its spatial distribution (Dayton et al., 1974; Knowlton and Highsmith, 2000; Page et al., 2011).

Doris kyolis (Ev. Marcus and Er. Marcus, 1967) (Nudibranchia, Dorididae) has been reported in tropical and subtropical locations of the western Atlantic, from Florida, USA, to Rio de Janeiro, Brazil (Belmonte et al., 2015; CaballerGutiérrez et al., 2015). Throughout its distribution range, it has been frequently observed in interaction with sponges

Submitted on: 29/May/2019

Approved on: 12/November/2019

Editor: Rubens M. Lopes

Associate Editor: Alexander Turra

(c) 2019 The authors. This is an open access article distributed under the terms of the Creative Commons license.
(Belmonte et al., 2015; Ortea et al., 2017) but there is no data of its density on the sponges from which it feeds. A recent study conducted in a southern Gulf of Mexico estuary (Laguna de Términos, Mexico) revealed that this nudibranch species is part of the associated macrofaunal assemblage with the sponge Halichondria (Halichondria) melanadocia Laubenfels, 1936 in seagrass meadows and red mangrove prop roots habitats (Ávila and Briceño-Vera, 2018). However, although $D$. kyolis was common in the samples of this sponge, basic aspects of its population dynamics, such as the small-scale spatial and temporal variation in its frequency of occurrence and density, have not been investigated. Therefore, the aim of the present study was to determine whether the frequency of occurrence and density of $D$. kyolis in association with $H$. (H.) melanadocia varies (i) between seagrass meadows and mangrove prop root habitats and (ii) throughout the year as a function of the sponge prey size and/or environmental factors, such as water temperature and salinity.

Samplings of $H$. (H.) melanadocia were carried out in the Laguna de Términos (Campeche, Mexico) in the southern Gulf of Mexico. Within this tropical estuarine system, two sampling sites (at a distance of $4.5 \mathrm{~km}$ from each other) were chosen: a red mangrove prop root habitat (Rhizophora mangle Linnaeus, 1753) $\left(18^{\circ} 40^{\prime} 23^{\prime \prime} \mathrm{N}-91^{\circ} 41^{\prime} 48^{\prime \prime} \mathrm{W}\right)$ and a seagrass meadow (Thalassia testudinum Banks ex König, 1805 mixed with Halodule wrightii Ascherson, 1868) $\left(18^{\circ} 44^{\prime} 29^{\prime \prime} \mathrm{N}-91^{\circ} 32^{\prime} 05^{\prime \prime} \mathrm{W}\right)$. In both sites, ten individuals of $H$. (H.) melanadocia were collected randomly (between 10:00 am and 12:00 pm and at depths of 0.5 to $0.8 \mathrm{~m}$ ) at monthly intervals from March 2014 to March 2015. No samples were obtained in January 2015. Each sponge collected was first covered with 
a plastic bag and detached from the substrate with a knife, and then the bag was closed immediately to prevent the loss of the associated nudibranch $D$. kyolis. During field samplings, observations were also made in order to make a brief description of the interaction.

The water temperature $\left({ }^{\circ} \mathrm{C}\right)$ was recorded daily at 12:00 $\mathrm{h}$ using a temperature sensor (HOBO Water Temp Pro v2 U22-001 data logger) tied in a stake at $20 \mathrm{~cm}$ from the bottom. Salinity of the bottom was measured on each sampling date by using a multiparameter sensor (YSI-63, Yellow Springs, OH, USA).

In the laboratory, nudibranchs were separated from the sponge by using dissecting forceps. Also, the seawater in the bags was filtered through a sieve (mesh size of $2 \mathrm{~mm}$ ) to recover those nudibranchs that could have detached from the sponge during transport (Ribeiro et al., 2003). Based on the presence of $D$. kyolis on the sponges examined, its frequency of occurrence (hereafter frequency) was calculated as the percentage of sponges that contained this nudibranch species at each site monthly. Its density was expressed as the average number of individuals per sponge and as the number of individuals per sponge volume. The volume $(\mathrm{mL})$ of each sponge was measured by using the fluid displacement method (Rützler, 1978). Also, the size (total body length) of each $D$. kyolis was measured with a Vernier (mm). After this, nudibranchs were returned to their original field sites.

Additionally, to verify if this nudibranch feeds on $\mathrm{H}$. $(H$.$) melanadocia, ten specimens of D$. kyolis were kept (individually) for four or five hours in Petri dishes with water from the site until they deposited their feces. Then, their feces were analyzed with an optical microscope to search for $H$. (H.) melanadocia spicules.

To determine whether the frequency and density of $D$. kyolis and the volume of $H$. $(H$.) melanadocia significantly vary throughout the study period (12 months) and between habitats (seagrass meadow and mangrove roots), the non-parametric analysis of variance of Kruskal-Wallis was used, with a posteriori Mann-Whitney U-test for comparisons between groups. The Shapiro-Wilk's and Levene's tests were used to check normality of the distribution and variance homogeneity of the data (frequency of occurrence and density of $D$. kyolis), respectively (Zar, 1984). To evaluate relationships between the frequency and density (individuals/sponge volume) of $D$. kyolis and the temporal variations of water temperature, salinity, and sponge volume, Spearman's rank correlation coefficient $\left(r_{s}\right)$ was used. Multiple regression analyses were also performed to investigate whether monthly data of temperature, salinity and sponge volume could significantly predict the density and frequency of occurrence of $D$. kyolis on the sponge.

Individuals of $D$. kyolis (size range from 6.7 to 17.4 $\mathrm{mm}$, average $\pm \mathrm{SE}=10.3 \pm 0.58 \mathrm{~mm}, \mathrm{n}=158$ ) as well as its ribbon eggs (of yellow color and spiral-like form) were always found between branch bases of $H$. $(H$.) melanadocia (Figure $1 \mathrm{~A}, \mathrm{C}$ ). In this interaction, $D$. kyolis has a color (dark gray, almost black) and texture similar to its sponge prey (mimicry strategy). Unlike other nudibranchs with aposematic coloration, this species has a cryptic coloration that makes it difficult to distinguish from the sponge (Figure $1 \mathrm{~A}$ ).

This nudibranch was present in $30 \%$ of the total sponge individuals examined $(n=240)$, with an overall density ranging from 1 to 13 individuals/sponge and from 0.004 to 0.097 individuals $/ \mathrm{mL}$ of sponge. Its frequency and density in $H$. $(H$.) melanadocia varied significantly between habitats (KW tests, $p<0.01$, respectively), being significantly higher (Mann-Whitney $U$-tests, $p<0.05$ and $p<0.01$, respectively) in the seagrass habitat (mean frequency $=39 \pm 5.2 \%$; mean density $=0.9 \pm 0.2$ individuals/sponge) than in those from mangrove roots ( $21 \pm 5.0 \%$ and $0.3 \pm 0.1$ individuals/sponge) (Figure $2 \mathrm{~B}, \mathrm{D}$ ). Both the frequency and density of $D$. kyolis did not vary significantly (KW tests, $p>0.05$, in both cases) throughout the year (Figure 2A, C). In the same way, the volume of the sponges $(50-900 \mathrm{~mL})$ varied significantly between habitats (KW test, $p<0.05$ ) but not throughout the year (KW test, $p>0.05$ ). Individuals from the seagrass habitat $(377 \pm 21 \mathrm{~mL}$ ) had a volume significantly higher (MannWhitney $U$-tests, $p<0.05)$ than those from the mangrove roots $(304 \pm 18 \mathrm{~mL})$. There were also no significant relationships between these population descriptors and the sponge volume, water temperature $\left(25^{\circ} \mathrm{C}-31.2^{\circ} \mathrm{C}\right)$, and salinity (25-36.6). Regarding the multiple regression analyses, the results indicated that the models were not a significant predictor of the intra-annual variability of frequency (adjusted- $R^{2}=-0.03$, ANOVA: $F_{[3,8]}=0.88$, $p>0.05$ ) and density (adjusted- $R^{2}=0.07$, ANOVA: $F_{[3,8]}=$ $1.31, p>0.05$ ) of $D$. kyolis.

After examining the feces of $D$. kyolis, only spicules (oxeas fusiform with acerate sharp point: 109 - [245] $-540 \mu \mathrm{m}$ length $\times 4-[8.4]-15 \mu \mathrm{m}$ wide) were found, which corresponded to those of $H$. $(H$.) melanadocia (Figure 1B). This finding confirms its predatory activity 


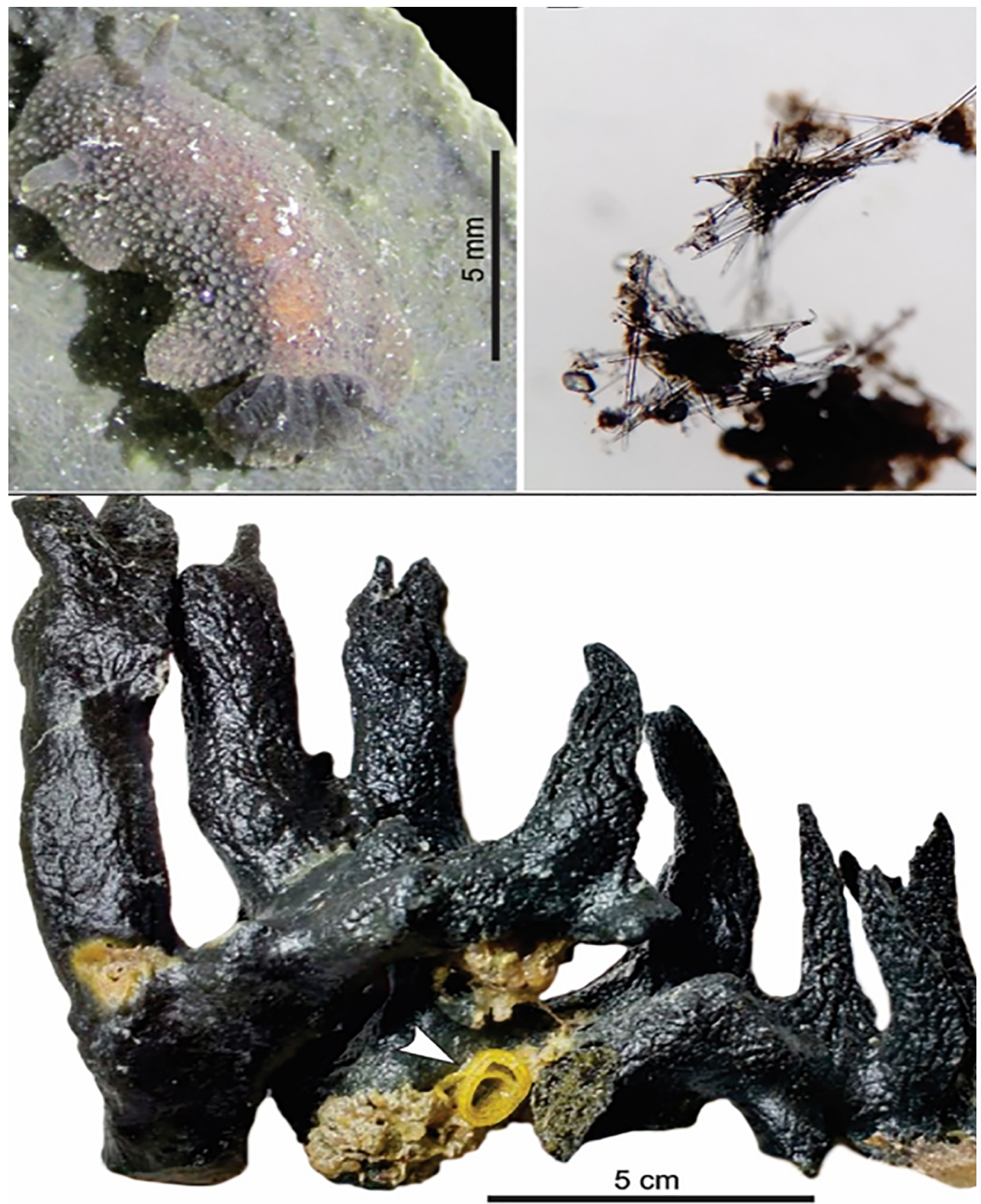

Figure 1. a) The nudibranch $D$. kyolis feeding on the sponge $H$. (H.) melanadocia. b) Spicules (oxeas) and tissue remnants of $H$. (H.) melanadocia found in the feces of $D$. kyolis. c) The arrow indicates egg ribbons of $D$. kyolis in the base of the sponge.

and likely specificity for this sponge species in the study area. Despite this, it was not possible to detect extensive damage in the sponge individuals where $D$. kyolis was found. Only superficial marks were observed in its ectosome.

This is the first formal record of $D$. kyolis as predator of the sponge $H$. $(H$.) melanadocia and is reported for the first time from the southern Gulf of Mexico. Although this nudibranch species has been reported in different tropical and subtropical regions of the western Atlantic, the sponge $H$. $(H$.) melanadocia had not been reported as its prey. Some of the characteristics of this nudibranch such as the mimicry coloration, agree with previous reports of this species from other locations, where it has been mentioned that its color depend on the sponges on which it feeds (Ortea et al., 2017). Also, its specific location in the 


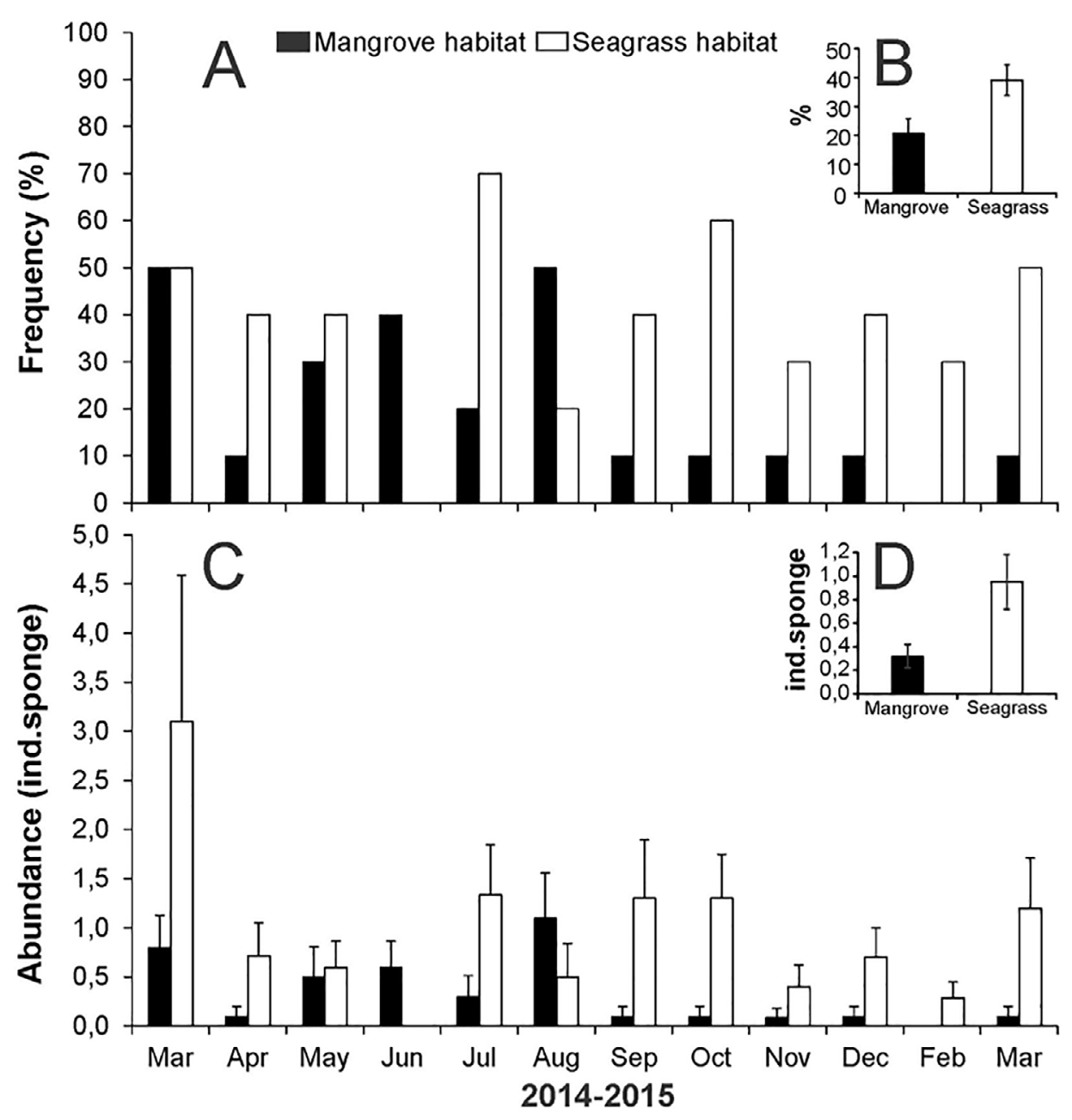

Figure 2. a) Intra-annual variability of the frequency of $D$. kyolis in the $H$. $(H$.) melanadocia samples from the seagrass meadow and mangrove prop roots and b) overall average frequency per habitat. c) Intra-annual variability of the average density ( \pm standard error) of $D$. kyolis in the $H$. $(H$.) melanadocia samples from the seagrass meadow and mangrove prop roots and d) overall average density per habitat.

sponge (between branch bases) may suggests an active site selection on the part of this nudibranch as has been documented in other sponge-feeding opisthobranchs (Becerro et al., 2003). These characteristics could help $D$. kyolis to hide from possible predators.

Regarding its density on $H$. (H.) melanadocia, it seems to be moderate in comparison with that reported in other sponge-eating opisthobranchs. For example, in Glossodoris pallida (Rüppell and Leuckart, 1830), which feeds on the sponge Hyrtios erecta (Keller, 1889) from Guam, a mean density of 1-3.4 individuals/sponge was reported (Rogers and Paul, 1991). Also, in the case of Hoplodoris nodulosa (Angas, 1864) (from Pelorus Sound, New Zealand) densities of up to 2,983 individuals per $100 \mathrm{~g}$ wet weight of the sponge Mycale hentscheli (Bergquist and Fromont, 1988) were reported (Page et al., 2011). Although the density of $D$. kyolis does not seem to be so high and that does not cause significant lesions in the sponge, it is known that these small predators (in high densities) may play a role in regulating the populations of their sponge prey (Dayton et al., 1974), especially in species under culture conditions (Page et al., 2011), even influencing its small-scale spatial distribution (Knowlton and Highsmith, 2000).

Notwithstanding that $H$. $(H$.) melanadocia inhabits in both seagrass meadows and mangrove root environments in the study area, the frequency of occurrence and density of $D$. kyolis in this sponge varied significantly between these two habitats. In this 
regard, some studies in nudibranchs have suggested that its spatial distribution can be a result of both habitat preference (in relation to a food source) and aggregation behaviors (in order to facilitate the reproductive process) (Darumas et al., 2007; Hubner, 2011). However, given the closeness of these habitats in the study area (less than $20 \mathrm{~m}$ in some sites) and that the dietary species is present in both, it is also possible that the small-scale spatial distribution of this nudibranch is linked to other factors such as predation, i.e. the structural complexity of the seagrass meadow could offer greater protection against potential $D$. kyolis predators than the mangrove root network. This smallscale variation has also been recorded in other members of the macrofauna associated with $H$. (H.) melanadocia in the same study area (Ávila and Ortega-Bastida, 2015). That study documented the spatial variability (between habitats) in the composition and overall density of associated macroinvertebrates with this sponge and it was mentioned that it may be due to a set of factors such as variations in the sponge morphology (related with its phenotypic plasticity), environmental conditions (e.g. sedimentation rate and light intensity), substrate orientation and the fauna inhabiting the surrounding area (Ávila and Ortega-Bastida, 2015).

Moreover, the frequency and density of $D$. kyolis did not vary significantly throughout the year and were not related with the sponge volume, temperature and salinity. These findings agree with those of previous studies where the temporal variability of nudibranchs has been associated with the presence of the food source rather than with variations in environmental conditions such as water temperature (Aerts, 1994). This relative stability in the population of $D$. kyolis appears to be explained by the abundant and perennial food source that $H$. $(H$.) melanadocia represents in the study area (Ávila et al., 2015). Another study also documented that temporal variations in the abundance and species diversity of intertidal nudibranchs were correlated with wave action, i.e. lower values being recorded during times of storms (Nybakken, 1978). Although the region where this study was conducted has a well-defined storm season (JuneOctober), there was no significant change in frequency and density of this nudibranch during that period.

There was also some evidence that $D$. kyolis could have specificity for $H$. $(H$.) melanadocia in the study area, since in addition to finding only remains of this sponge in its feces, it was not observed preying on other sponge species, as has been documented in other dorid species (Penney, 2013). However, this result contrasts with that of Belmonte et al. (2015) who reported to $D$. kyolis as a polyphagous species in a region outside the distribution range of $H$. (H.) melanadocia (Rio de Janeiro, Brazil). There, $D$. kyolis preys on sponges of different taxonomic groups such as Dysidea etheria, Haliclona sp., Lissodendoryx (Lissodendoryx) isodictyalis (Carter, 1882) and Plakina sp. Schulze, 1880 (Belmonte et al., 2015). In this sense, it has been documented that some dorid nudibranch species can have a plastic polyphagous diet (e.g. Platydoris argo), i.e., they can feed on other sponges when the main prey species is unavailable or even the preferred prey can change from one habitat to another (Megina et al., 2001). Thus, to determine whether $D$. kyolis is a stenophagous or polyphagous feeder further studies are required.

In summary, this study contributes to knowledge of the relationship between the nudibranch $D$. kyolis and the sponge $H$. $(H$.) melanadocia, mainly on basic aspects of its population dynamics such as the frequency of occurrence and density of the nudibranch on the sponge and its spatio-temporal variability. However, it would be advisable for future studies to determine whether this predator has the ability to choose between different sponge preys as food source and whether it acquires secondary metabolites from the sponge for its own defense.

\section{ACKNOWLEDGEMENTS}

This study was funded by the Universidad Nacional Autónoma de México (internal project no. 618). We thank Hernán Álvarez-Guillén, Andrés Reda-Deara and Alejandro Gómez-Ponce for their assistance with field samplings. The authors appreciate the English proofreading service done by Dra. Karen Englander.

\section{AUTHOR CONTRIBUTIONS}

E.A.: Conceptualization; Writing - original draft; Writing

- review \& editing; Funding acquisition.

Y.C.M.: Investigation; Writing - review \& editing.

M.A.R.S.: Methodology; Writing - review \& editing.

M.B.: Supervision; Validation; Writing - review \& editing. 


\section{REFERENCES}

AERTS, L. A. M. 1994. Seasonal distribution of nudibranchs in the southern Delta area, SW Netherlands. Journal of Molluscan Studies, 60, 129-139.

ÁVILA, E., ÁVILA-GARCíA, A. K. \& CRUZ-BARRAZA, J. A. 2015. Temporal and small-scale spatial variations in abundance and biomass of seagrass-dwelling sponges in a tropical estuarine system. Marine Ecology, 36, 623-636.

ÁVILA, E. \& BRICEÑO-VERA, A. E. 2018. A reciprocal inter-habitat transplant reveals changes in the assemblage structure of macroinvertebrates associated with the sponge Halichondria melanadocia. Estuaries and Coasts, 41, 1397-1409.

ÁVILA, E. \& ORTEGA-BASTIDA, A. L. 2015. Influence of habitat and host morphology on macrofaunal assemblages associated with the sponge Halichondria melanadocia in an estuarine system of the southern Gulf of Mexico. Marine Ecology, 36, 1345-1353.

BECERRO, M. A., PAUL, V. J. \& STARMER, J. 1998. Intracolonial variation in chemical defenses of the sponge Cacospongia $\mathrm{sp}$. and its consequences on generalist fish predators and the specialist nudibranch predator Glossodoris pallida. Marine Ecology Progress Series, 168, 187-196.

BECERRO, M. A., TURON, X., URIZ, M. J. \& TEMPLADO, J. 2003. Can a sponge feeder be a herbivore? Tylodina perversa (Gastropoda) feeding on Aplysina aerophoba (Demospongiae). Biological Journal of the Linnean Society, 78, 429-438.

BELMONTE, T., ALVIM, J., PADULA, V. \& MURICY, G. 2015. Spongivory by nudibranchs on the coast of Rio de Janeiro state, southeastern Brazil. Spixiana, 38, 187-195.

CABALLER-GUTIÉRREZ, M. C., ORTEA, J., RIVERO, N., TUCKER, G. C., MALAQUIAS, M. A. E. \& NARCISO, S. 2015. The opisthobranch gastropods (Mollusca: Heterobranchia) from Venezuela: an annotated and illustrated inventory of species. Zootaxa, 4034, 201-256.

DARUMAS, U., CHAVANICH, S. \& SUWANBORIRUX, K. 2007. Distribution patterns of the renieramycin-producing sponge Xestospongia sp. and its association with other reef organisms in the Gulf of Thailand. Zoological Studies, 46, 695-704.

DAYTON, P. K., ROBILLIARD, G. A., PAINE, R. T. \& DAYTON, L. B. 1974. Biological accommodation in the benthic community at McMurdo Sound, Antarctica. Ecological Monographs, 44, 105-128.
HUBNER, G. 2011. Nudibranch neighborhood: the distribution of two nudibranch species (Chromodoris lochi and Chromodoris sp.) in Cook's bay, Mo'orea, French Polynesia. UC Berkeley, Student Research Papers, 1-10.

KNOWLTON, A. L. \& HIGHSMITH, R. C. 2000. Convergence in the time-space continuum: A predator-prey interaction. Marine Ecology Progress Series, 195, 285-291.

MEGINA, C., CARBALLO, J. L., CERVERA, J. L. \& GARCÍA-GÓMEZ, J. C. 2002. The diet of Platydoris argo (Gastropoda: Nudibranchia) and the dietary specialization of sponge eating dorids. Journal of Molluscan Studies, 68, 173-179.

NYBAKKEN, J. 1978. Abundance, diversity and temporal variability in a California intertidal nudibranch assemblage. Marine Biology, 45, 129-146.

ORTEA, J., ESPINOSA, J. \& MORO, L. 2017. Nueva especie y nuevos registros de dóridos (Gastropoda: Heterobranchia: Doridina) para la isla de Cuba. Avicennia, 20, 1-6.

PAGE, M. J., HANDLEY, S. J., NORTHCOTE, P.T., CAIRNEY, D. \& WILLAN, R. C. 2011. Successes and pitfalls in the aquaculture of the sponge Mycale hentscheli. Aquaculture, 312, 52-61.

PENNEY, B. K. 2013. How specialized are the diets of Northeastern Pacific sponge-eating dorid nudibranchs? Journal of Molluscan Studies, 79, 64-73.

RIBEIRO, S. M., OMENA, E. P. \& MURICY, G. 2003. Macrofauna associated to Mycale microsigmatosa (Porifera, Demospongiae) in Rio de Janeiro State, SE Brazil. Estuarine, Coastal and Shelf Science, 57, 951-959.

ROGERS, S. D. \& PAUL, V. J. 1991. Chemical defenses of three Glossodoris nudibranchs and their dietary Hyrtios sponges. Marine Ecology Progress Series, 77, 221-232.

RUDMAN, W. B. \& BERGQUIST, P. R. 2007. A review of feeding specificity in the sponge-feeding Chromodorididae (Nudibranchia: Mollusca). Molluscan Research, 27, 60-88.

RÜTZLER, K. 1978. Sponges in coral reefs. In: STODDART, D. R. \& JOHANNES, R. E. (eds.) Coral reefs: research methods, Monographs on Oceanographic Methodology. Paris: UNESCO, 209-313.

WÄGELE, H., BALLESTEROS, M. \& ÁVILA, C. 2006. Defensive glandular structures in Opisthobranch molluscs-from histology to ecology. Oceanography and Marine Biology: An Annual Review, 44, 197-276.

ZAR, J. H. 1984. Biostatistical analysis. Englewood Cliffs, NJ, Prentice-Hall. 